\title{
E. U. Customs Obligation
}

\author{
Marco Lupi \\ Jonico Department-University of Bari Aldo Moro, Taranto, Italy \\ Email: lupimarco18@tiscali.it
}

How to cite this paper: Lupi, M. (2019). E. U. Customs Obligation. Beijing Law Review, 10, 10-22. https://doi.org/ 10.4236/blr.2019.101002

Received: October 10, 2018

Accepted: January 15, 2019

Published: January 18, 2019

Copyright $\odot 2019$ by author(s) and Scientific Research Publishing Inc. This work is licensed under the Creative Commons Attribution International License (CC BY 4.0).

http://creativecommons.org/licenses/by/4.0/

(c) (i) Open Access

\begin{abstract}
In a world that is increasingly globalized and open to trade, customs law has become increasingly central to businesses and consumers. From 1 May 2016 there has been a real revolution in customs: in fact, many of the provisions contained in the EU regulation no. 952/2013 which established the new EU Customs Code. The new simplifications are based on a more intense digitalization of the dialogue between the company and customs and they aim to both reduce the time spent on customs clearance, and also to provide external users with the traceability of the entire import/export cycle and the carrying out of controls connected. The transition to the new one, however, was not clear, but in order to protect the legitimate interests of the economic operators and to guarantee the validity of the decisions taken and the authorizations issued in force of the previous Union customs legislation, a transitional period was envisaged, until 1 May 2019, to allow the adaptation of these decisions and authorizations to the new legal provisions (reassessment). This contribution analyzes, in light of the new rules of the code, the conditions in relation to which the customs debt and the taxable persons required to fulfil the obligations arise. Finally, brief elements are dedicated to the settlement of customs duties, such as the classification of goods, having regard to the indications provided by the Common Customs Tariff, the origin and value of products. This electronic document is a "live" template. The various components of your paper [title, text, heads, etc.] are already defined on the style sheet, as illustrated by the portions given in this document.
\end{abstract}

\section{Keywords}

Customs Duty-Duty on Goods to Be Re-Exported, the Customs Debt Irregular Goods, Customs Debt and VAT-Customs Bond and Illegal Goods, Joint Liability Obligation 


\section{Introduction}

The obligation is the juridical relationship (iuris vinculum according to the definition of Justinian's Institutions) by virtue by which a person, called debtor, has the duty to perform a certain service to another named creditor. The latter has the right to demand the benefit which constitutes the object of the obligation (for example, the repayment of the sum given as a bank loan together with the payment of the agreed interest or the payment of the tax in the case of a public-law obligation) and can exercise his relative power (Breccia U., 1991, Bianca M., 1993). ${ }^{1}$ The object of the customs debt on importation (or export) is made up the payment of the duties provided by the Union Customs Tariff for each category of goods covered by the customs operation (Article 56$)^{2}$. It should be remembered that the Customs Tariff (Daniele L., 1988, Palcchino T., 2004) ${ }^{3}$ includes the following elements:

1) The combined nomenclature of goods referred to in Reg. (CEE) n. 2658/87 of the Council (which replaced the previous EEC Regulation of 28 June 1968, No. 950);

2) Any other nomenclature that duplicates entirely the Combined Nomenclature in or in part or provides any further subdivisions of the nomenclature and which is established by specific Union provisions for the application of tariff measures in the context of goods exchange;

3) The conventional or autonomous customs duties applicable to the goods covered by the Combined Nomenclature;

4) The preferential tariff measures contained in agreements which the Union has concluded with certain countries or territories not forming part of its customs territory or with groups of such countries or territories;

5) The preferential tariff measures adopted unilaterally by the Union in respect of certain countries or territories which are not part of its customs territory or groups of such countries or territories;

6) The autonomous measures which provide the reduction or exemption from duties on certain goods;

7) Favourable tariff treatment specified for certain goods, due to their nature or their final use;

8) The other tariff measures provided by agricultural, commercial or other Union legislation.

All the elements are summarized in the Common Integrated Tariff (TARIC), which, although it is not legally effective, summarizes the European Union measures applicable to the goods being imported (customs duties, agricultural ${ }^{1}$ Breccia U. (1991). The Obligations (p. 21 and the following pages). In the Treaty of civil law Publisher Giuffrè. Bianca M (1993). The Obligations (ch. IV Italian Civil Code). Handbook Publisher Giuffre. Bianca M. (2000). The Obligations (ch. IV Italian Civil Code). Handbook Publisher Giuffre. ${ }^{2}$ Regulation (Eu) No 952/2013 of the European Parliament and of the Council of 9 October 2013 establishing the Union Customs Code.

${ }^{3}$ On topic see Daniele L. (1988): "Movement of goods in Community law”. In Dig. disc. publ., vol. III (p. 60 ss.). Palcchino T. (2004): The Community Tax Law (pag. 155 ss). 
duties and anti-dumping duties, tariff quotas and tariff preferences) constituting an effective operational which is now completely digitalised and easy to use ${ }^{4}$.

\section{The Customs Obligation in the European Union Code}

The Union Customs Code has regulated the customs debt regime under Articles 77 ss., Anticipating the treatment of the matter with respect to the code of 1992, which regulated the customs obligation in articles. 201 ss. The Union code, in fact, has rationalized the of customs provisions by anticipating the treatment of institutions of a general nature (rights and obligations of persons, provision of information by the Offices, customs representation, decisions concerning the application of customs legislation, discipline of the authorized economic operator, sanctions and appeals) ${ }^{5}$ compared to the regulation of the introduction of goods (articles 127 ss.) and of the individual customs procedures (articles 201 ss.) (Cerioni F., 2013) ${ }^{6}$.

The article 77 provides that: "a customs debt on importation arises as a result of the non-Union goods being subject to import duty under one of the following customs procedures":

1) Release for free circulation, including the end-use regime;

2) Temporary admission with partial exemption from import duties.

The customs debt arises "at the time of acceptance of the declaration" and, as a rule, at the place where the declaration is presented, or at the place where the operative event occurs, if different from the declaration (Article 87 European Union Code). The article 77, paragraph 3, identifies the debtor in the person of the "declarant". In the case of indirect representation-that the customs transaction is carried out in its own name but on behalf of the represented person (Pugliatti S., 1935, Luminoso A., 1984, Bianca M., 2000) ${ }^{7}$, whose name must in any case be indicated on the customs declaration for the purpose of extending the

\footnotetext{
${ }^{4}$ Article 57 Union Customs Code: the customs classification of an asset is the process leading to the attribution of a customs code corresponding to a tariff position of the Common Customs Tariff. It is of primary importance to attribute the correct customs code to a product as it carries with it the determination of import duty and any restrictive measures both on import and export Classifying a good means giving it a numerical code from 2 to 10 digits (additional digits or additional codes can be entered for statistical or commercial policy reasons) depending on the needs that typically can reach up to 10 digits. The customs code required for exports is 8-digit and takes the name of Combined Nomenclature or $\mathrm{NC}$ whereas the customs code required for imports is 10 digits and is called TARIC. The correspondence system between goods and numerical codes is called the Harmonized System (HS or Harmonized System-HS) and is managed by the World Customs Organization (OMD or World Customs Organization-WCO). This harmonization concerns the first 6 digits of the Customs Code (sub-heading or sub-heading) and causes them to be the same for that particular asset in all 180 WCO member countries. Seventh and eighth digit, which make up the NC and ninth and tenth digits, which make up the TARIC are harmonized at the level of the European Union and, therefore, are the same in all the Member States of the Union.

${ }^{5}$ Artt. 6-45 del Reg. UE n. 952/2013.

${ }^{6}$ On topic see Cerioni F. (2013): Entry into force of the European Union Customs Code (pag. 3648 ss).

${ }^{7}$ On topic see Pugliatti S. (1935): Institutiones Civil Law. In Legal Writings, vol. I (pag. 645 ss.). Luminoso A. (1984): Mandate, Commission, Expedition (pag. 5 ss.). Bianca M. (2000): Italian Civil Code (pag. 120 ss.).
} 
obligation (Parlato A., 1963, Castaldi L., 1993) ${ }^{8}$ the name of the person on whose behalf the declaration has been made to which the customs administration may extend the customs debt must also be indicated. The represented one/agent will be responsible of tax with the representative/mandatary; in fact, among the two relationship of juridical solidarity subsists in comparison to the customs obligation. This even if to load of the represented one the presuppositions of tax don't subsist fixed by the law (as required by art. 19 European Union Code) ${ }^{9}$. A debtor is also deemed to be the person who has "provided the data necessary for the preparation of the declaration and was, or should reasonably have been, aware of their erroneousness, when they caused the total or partial non-payment of import duties (think of the wrong determination or false attestation of the origin of a commodity which results in total exemption or reduction of import duties) ${ }^{10}$. It is clear that this joint and several liability attaches to the person who supplied incorrect data to the declarant the position of tax manager, as the latter is bound "ex lege" to the payment of customs duties (including agricultural and anti-dumping duties) despite not having achieved the above mentioned conditions of taxation (release for free circulation or temporary admission with only partial exemption from import duties) $)^{11}$.

\section{New Formulation of the Ban on Double Duty Facility}

The art. 75 of the code has developed to a new formulation of the ban on double duty benefits already established by art. 216 of the 1992 Code, which, as specified by the Customs Agency, aims to prevent the operator from benefiting from a dual advantage in the context of a processing operation, benefiting, on the one hand, from the exemption for imported goods used in production processes and, on the other hand, preferential tariff treatment for goods re-exported from one of the countries participating in the agreement, with a certificate attesting the origin of the EU, as if it were goods produced entirely in a member state of the European Union (Castaldi L., 1993) ${ }^{12}$.

The art. 75 of the code has proceeded to a new formulation of the ban on ${ }^{8}$ On topic see Parlato A. (1963): The Tax Manager (p. 79 ss). Castaldi L. (1993): Tax obligation jointly liable (pag. 1 ss.).

${ }^{9}$ Similarly Union Custom Code art. 201 of the 1992.

${ }^{10}$ In the AIDA system (Integrated Customs Authority, the information system of the Customs and Monopolies Agency, operational since 10 November 2003), the "Representatives Database" was created, containing the subjects to whom the power of representation at customs is recognized. This database was preloaded with the information held by the Agency, inserting, as direct representatives, pursuant to art. 18 of the $\mathrm{CDU}$ and national provisions: the doganalists registered in the register; 1 ) the doganalists registered in the register; 2) Customs Assistance Centers-CAD, registered in the register; 3) subjects who have been granted AEOC/F status-Authorized Economic Operators with Customs or Full status) With regard to the last category, it should be noted that, with the new rules, the status of Authorized Economic Operator is no longer assigned with a certification but with two different types of authorization: AEOC (customs simplification sector) and AEOS (security sector) "safety and security"). If the requirements for both licenses are met, a combined authorization is issued that guarantees the cumulative benefits of AEOC + AEOS.

${ }^{11}$ On topic see footnote in main text 8 .

${ }^{12}$ On topic see Castaldi L. (1993). Jointly liable custom (ad vocem). In the Enciclopedia Giuridica vol. XXIX Publisher Treccani. 
double duty benefits already established by art. 216 of the 1992 Code, which, as specified by the Customs Agency, aims to prevent the operator from benefiting from a dual advantage in the context of a processing operation, benefiting, on the one hand, from the exemption for imported goods used in production processes and, in the second place, preferential tariff treatment for goods re-exported from one of the countries participating in the agreement, with a certificate attesting the origin of the EU, as if it were goods produced entirely in a Member State of the European Union.

The article 75 of the Union Code provides for the application of import duties on products not originating in the EU used under an inward processing procedure at the time of acceptance of the "re-export declaration" relating to "processed products"13, for which a proof of the Union origin of the products themselves is issued, where there is a prohibition on reimbursement or exemption from import duties on non-originating goods used in the production process.

In fact, it should be recalled that the inward processing regime (Article 256 of the Union Code) allows non-Union goods to be used in the customs territory of the Union for certain processing operations ("processing operations"), without application of import duties and of the restrictive measures provided for by the rules on commercial policy (it constitutes an alternative to the drawback system, based on facilitating processing operations within the country by means of the export refund of customs duties paid on imported raw materials $)^{14}$. Even if it was envisaged by the 1992 Customs Code, this scheme (Muratori A., 1980, Cerioni F., 2006) ${ }^{15}$ is now regulated under special schemes, including transit, deposit, final use and inward and outward processing (Article 210) ${ }^{16}$.

\section{The Customs Obligation Caused by the Illegitimate Importation of the Commodities}

The article 76 of the Union Code established, in a single provision, the condition of the obligation deriving from the non-compliance with the customs legislation previously connected to various illicit cases. According to the 76 article, the obligation to pay import duties derives not only from the release for free circulation of goods subject to import duties, but also from non-compliance:

1) One of the obligations established by customs legislation about the introduction of non-Union goods into the customs territory of the Union, also their removal from customs supervision or for circulation, processing, storage, temporary admission or removal of such goods within that territory;

2) One of the obligations laid down by customs legislation concerning of goods placed under the final-use procedure within the customs territory of the Union;

\footnotetext{
${ }^{13}$ See the note from the Italian customs agency, duty management area, 18 July 2003, prot. n. 2364. ${ }^{14}$ They are "transformed products", pursuant to art. 5, n. 30, of the EU Reg. N. 952/2013, those resulting from a process of improvement. They are the "old" compensating products foreseen by the art. 114, par. 2, lett. d) of the 1992 Customs Code.

${ }^{15}$ For further information on this point see refences.

${ }^{16}$ Artt. 114 ss. del Reg. CEE 2913/1992.
} 
3) A condition established for the placing of non-Union goods under a customs procedure or for the granting of an exemption or a benefit relating to the end-use procedure.

Failure to comply with the customs legislation may result from the illegal introduction of goods into the territory of the Union, as required by art. 202 of the CEE Reg. 2913/1992, as well as from the introduction of goods into the territory of the European Union without the goods being subjected to customs control, pursuant to art. 203 of the same regulation. ${ }^{17}$ The introduction of goods without customs control can occur in two forms: the irregular introduction of goods, the removal of goods from customs control. Goods which, having crossed the land border of a state of the European Community, are in that territory beyond the first customs office without having been subject to control by the customs authority are considered to have been "irregularly introduced". The notion of "subtracting" from customs control, on the other hand, must be understood to include any action or omission which results in preventing, even temporarily, the competent customs authority from accessing goods under customs supervision and carry out the controls required by the customs regulations (these are the cases of goods in transit that are not presented within the time limits set at the Office of destination or the theft of goods from customs warehouses ${ }^{18}$ customs control, pursuant to art. 203 of the same regulation. The introduction of goods without customs control can occur in two forms: the irregular introduction of goods, the removal of goods from customs control. Goods which, having crossed the land border of a state of the European Community, are in that territory beyond the first customs office without having been subject to control by the customs authority are considered to have been "irregularly introduced". The notion of "subtracting" from customs control, on the other hand, must be understood to include any action or omission which results in preventing, even temporarily, the competent customs authority from accessing goods under customs supervision and carry out the controls required by the customs regulations (these are the cases of goods in transit that are not presented within the time limits set at the Office of destination or the theft of goods from customs warehouses $)^{19}$. In cases such as those listed above of illicit introduction or removal from customs controls, the code obliges the payment of duties a large number of subjects, considering "debtors": the person who was required to meet the obligations under the customs provisions or who knew or should reasonably have known (Russo P., 2003) ${ }^{20}$ that an obligation under the customs legislation had not been respected and acted on behalf of the person obliged to comply with the obligation, or who participated in the act which gave rise to non-compliance ${ }^{17}$ Art. 210 del Reg. UE n. 952/2013.

${ }^{18}$ In these terms, EC Court of Justice, 3 March 2005, case C-195/03, Papismedov et al., Paragraph 26; Id., 2 April 2009, case C-459/07, Elshani, points 20 and 26.

${ }^{19}$ In these terms, EC Court of Justice, 11 July 2002, Case C-371/99, Liberaxim, paragraph 55, in GT Riv. swore. trib. n. 1/2003, p. 12, with commentary by L. Barone, 29 April 2004, case C-222/01, British American Tobacco, point 47; 20 January 2005, case C-300/03, Honeywell Aerospace, paragraph 19; 11 July 2013, case C-273/2012, Harry Winston SARL, paragraph 29.

${ }^{20}$ In the Handbook on Tax Law, Special Section, Russo P. (2009). Publisher Giuffrè. 
with the obligation ; and any person who has acquired or held the goods in question and who knew or should reasonably have known at the time he acquired or received them that an obligation under the customs legislation had not been complied with. The Court of Justice has repeatedly stated that the reference to persons in Articles 202 and 203 allows both natural and legal persons to be considered obligatory ${ }^{21}$. Therefore, in case of non-presentation to customs of goods that do not benefit from the domiciled customs clearance procedure, the importer, the customs agent, as well as the wholesaler to whom the goods are sold will be jointly liable. The persons above are directly responsible for the payment of customs duties, following the realization of the unlawful act which, however, always presupposes the introduction of the goods in free circulation. Therefore, if the obliged party can prove that the goods have been permanently lost or destroyed, or have been re-exported and that, therefore, the goods have not been neither consumed nor used, the obligation lapses pursuant to art. 124. Those who participate in the illegal introduction or removal will respond as main obligations, similarly to what established by art. 36 of the D. P. R. September 29, 1973, n. 602, for liquidators of companies or other entities subject to IRES (corporate income tax). The representative of the importer and those who held the illegal goods, the latter having the obligation to know where the goods come from, will be obliged as responsible for customs duty. In cases other than the previous, the non-observance of rules, such as those relating to restrictions on goods not coming from a European Union state or relating to assumptions on customs duties, will have consequences only on the importer and not on his representative. Therefore, the non-compliance will be settled only by the importer and not by his representative (customs agent). However, the representative will be obliged to pay the duties if he has provided the importer with incorrect data for the completion of the customs declaration or for the lack of professionalism in helping the importer in the customs operations (Article 79, paragraph 4). This last provision also puts the actual knowledge of the goods on the same level with the knowledge of the inaccuracy of the declared data which leads to the total or partial non-collection of import duties (Fiorenza S., 1990, Muratori A., 1993, De Cicco A., 2002, Russo P., 2002, Boria P., 2008, Falsitta G., 201022.

\section{Vat on Importation}

Consumption of goods in the territory of one of the Member States, which enters free circulation in the European Union, complements, at least in normal circumstances, the condition of import VAT (Padovani F., 2002) ${ }^{23}$. The article 70 of Directive 2006/112/CE of 28 November 2006 establishes that the chargeable

${ }^{21}$ Court of Justice of the EU, 22 September 2004, case C-414/02, Spedition Ulustrans.

${ }^{22}$ Articles 114 ss. of the Reg. CEE 2913/1992.

${ }^{23}$ S. Fiorenza S. (1990), "Customs and customs duties", in Dig. disc. priv., Sec. comm., vol. V, Turin, p. 124; Muratori A. (1993), Commentary on the single customs text, Padua, p. 55; A. De Cicco A. (2002), "Imports", in Enc. swore. Treccani, vol. XVI, Rome, pag. 1 ss. (ad vocem). Padovani F. (2002). Customs duties (p. 287 and the following pages). Publisher Giuffre. Boria P. (2008); The tax system, Turin, p. 824; Falsitta G. (2010), Handbook on Tax Law, Special Section, The Tax System in Italy, Padua, p. 893 ss. 
event of the customs tax occurs, and the tax becomes payable, when the importation of goods into the State is carried out. VAT and customs duties on imports have comparable essential characteristics, since they come from the introduction of goods into the Union the subsequent introduction into the economic circuit of the Member States. He article. 71, par. 1 of Directive 2006/112/CE, provides in the first subparagraph that, when the goods are bound, from the moment they enter the Union, to the customs warehousing procedure, the chargeable event of the tax and the chargeability of the tax occur only when the goods are released from the customs warehouse.

\section{Customs Duties on Illegal Goods}

The article 83 of the Union Code states that an obligation to import may arise even if the goods subject to the customs operation are subject to 'measures of any kind which prohibit or restrict their importation. However, the customs debt does not be born in the following cases:

1) Illegal introduction of false money into the customs territory of the Community;

2) Introduction into the Community's customs territory of narcotic drugs and psychotropic substances if not strictly controlled by the competent authorities to be used for medical and scientific purposes.

The text of the art. 83, in the part in which it refers to goods subject to restrictive measures of "any kind", is susceptible to a wider application than the previous provision, contained in the art. 212 of the 1992 Code, which referred to goods that had already been subject to a restrictive import measure. Although the Court of Justice has clarified that even narcotics are goods, the code only imposes duty imported into the legal circuit, while illegal drugs will be subjected to criminal confiscation and mostly intended for destruction and, therefore, will not give rise to any customs debt (Article 83, paragraph 2). Paragraph 3, of the art. 83, establishes, moreover, that the customs debt is considered for the purposes of quantifying tax penalties-of an administrative or penal nature-applicable to the unlawful introduction of goods, "when the legislation of a Member State provides that customs duties or the existence of a customs debt serves as a basis for determining the penalties". The provision in question, compared to that contained in art. 212 of the 1992 Code, correctly omits any reference to penal legislation, allowing the extension of the rule also for the purpose of calculating administrative sanctions.

\section{Jointly Liable to Duty Custom}

The Union Customs Code confirms the principle that when the same customs debt comes from a few debtors, they "are jointly and severally liable for the payment of that amount" (Article 84). If the customs debt is joint (and not partial), each of the co-debtors may be called by the tax authority to pay the whole, as provided for in Articles 1292 and 1294 Italian civil code (Giannini A. D., 1965) ${ }^{24}$. ${ }^{24}$ Court of Justice of the EU, 11 July 2013, Case C-273/2012, Harry Winston SARL, cit., Paragraphs $39-41$. 
These provisions govern the tax solidarity peacefully, in all cases in which in the individual tax laws there is no specific discipline of the institution ${ }^{25}$. It should be remembered that the doctrine has enucleated two types of fiscal solidarity: the joint and the employee. Solidarity is the same when the assumption of the tax is made by a plurality of subjects who, therefore, are held by virtue of a fact directly attributable to them (Potito E., 1989; Castaldi L., 1992; Fantozzi A., 2003; Falsitta G., 2003; Tesauro F., 2003) ${ }^{26}$. In a different way, solidarity is generated in the obligation when the tax provides for a principal obliged party, which creates the assumption of the customs tax and another subject submitted to the customs debt because of the assumption created by the first obliged subject. The second obliged subject is linked to the first subject obliged by law to have put in place a legal fact that determines a collateral obligation ${ }^{27}$. However, the provisions of the Union Code tend in many cases to place the customs debt on a person who does not fulfil the typical assumption of the obligation (release for free circulation or temporary admission) and therefore assumes the position of the person responsible for tax. These are the cases of the representative in the indirect representation, of the forwarder who indicates inaccurate data in the customs declaration (Article 77, paragraph 3), of the subjects involved in the operation in cases of irregular introduction or removal from customs controls (Article 79, para 3, letter b) (Parlato A. 1991).

\section{The Duty Customs Assessment}

The Union code confirms the competence of the customs office of the place where the duty customs arises as the competent authority to collect the duty from the obliged subject (Article 101) The obligation, in fact, arises in the place where the declaration is presented or, in the absence of a declaration, in the place where the condition required by the customs legislation occurs. If it is not possible to determine exactly this place, the obligation is deemed to have arisen in the place where the customs authority ascertains that the condition for the tax has occurred (Article 87). The amount of import duties must be determined by the customs office in accordance with the rules in force at the time the customs debt was incurred (Article 85) and then communicated to the debtor in the form

\footnotetext{
${ }^{25}$ Articles 1292 e 1294 italian civil code about passive jontly liable, the law states that: "the bond is in solidarity when several debtors are all obliged for the same benefit so that everyone can be forced to fulfill all and fulfillment by a free person. others" Giannini A. D. (1965), Institutions of Tax Law, Milan, 1965, p. 125.

${ }^{26}$ In fact, there is equal solidarity, when more than one person is jointly and severally obliged to fulfill the tax obligation for having contributed to the implementation of the tax situation. In the subject we can read E. Potito, "Passive tax person", in Enc. dir., vol. XLII, pag. 1226. L. Castaldi, "Solidarity tributary”, cit., Loc. cit., pag. 3 ss. (ad vocem). Fantozzi A. (2003), Tax law, Turin, 2003, p. 314 ss.. G. Falsitta, Manual of Tax Law, cit., Loc. cit., pag. 264 ss.. F. Tesauro, Institutions of Tax Law, cit., Loc. cit., pag. 126 ss.

${ }^{27}$ This figure that occurs every time a subject is called to fulfill the tax obligation even though he has remained extraneous to the realization of the case. For more information, please refer to A. Parlato, "Tax Responsibility", in Enc. swore. Treccani, vol. XXVII, Rome, 1991, and L. Castaldi, jointly liable custom (ad vocem). Enciclopedia Giuridica vol. XXIX Treccani.
} 
prescribed by national law as soon as it has all the necessary elements (Article 102). If the customs authority considers the amount indicated by the obligor as correct and proceeds with the release of the goods, the release is equivalent to the communication of the confirmation of the accuracy of the amount indicated (Article 102, paragraph 2). Otherwise, if the customs proceeds to rectify the declaration and the debtor does not immediately pay the amount of duties determined by the Office (provided that it is not authorized to deferred payment of the same), it will be necessary to notify the debtor an act of assessment. Together with the notification to the debtor of the amount of the duties to be paid, the Office must provide for the "accounting"-that is, the entry in the customs records-of the said duties (Article 104), within fourteen days from the release of the goods (article 105). The Office can proceed to a single accounting of all the customs debts that have arisen in a certain period at the end assessment (based on the system of the periodic payment of customs duties provided for by Article 78 of Presidential Decree January 23, 1973, No. 43). The Customs Offices cannot provide for the notification of debts to the debtor when:

1) Pending the definitive determination of the amount of the duties, a provisional commercial policy measure in the form of a duty has been established;

2) The amount of duties due exceeds the amount established based on a binding tariff information;

3) The initial decision not to notify the customs debt or to notify it with a figure lower than the amount of duty due has been made on the basis of general provisions subsequently invalidated by a judicial decision;

4) The customs authorities are exempted from a special customs provision from the obligation to notify the customs debt.

Note that when the new code comes into force the customs offices will no longer be able to avoid the accounting of customs duties, as now foreseen by art. 220 , par. 2, of the EEC Reg. 2913/1992, in the case of their own mistakes to the detriment of the obligors who were in good faith, as only the remission or repayment of duties is foreseen (Article 119). The limitation period for the notification of a customs debt assessment notice is three years from the date on which the obligation arose. However, when the obligation arises on the basis of an act (for example an episode of irregular introduction into the EU territory) that complements the case of the contraband crime, the limitation period is extended up to ten years (Article 103).

\section{Extinction of the Customs Debt}

The extinction of the customs debt must normally take place with the payment of the amount due. However, they constitute an extinctive means-not solvent-of the customs debt: the expiry of the prescription; the remission of the amount of the duty; the invalidation of the customs declaration; the confiscation 
(possibly preceded by the seizure) of the goods subject to the application of the duties; the destruction of goods under customs supervision or the abandonment of the goods to the State, in the event of total destruction or irretrievable loss of goods due to their nature, or by chance or force majeure, or by order of the customs authority, which determine the absolute uselessness of the same by anyone (Article 124). In cases of customs debt arising as a result of "non-compliance" pursuant to art. 79 (or 82) of the Union Code, the tax liability of the obligor is extinguished when:

1) The non-fulfilment which led to the creation of the customs debt had no significant effect on the proper functioning of the customs procedure in question and was not an attempt at fraud;

2) All the formalities necessary to regularize the situation of the goods are subsequently carried out;

3) Evidence that they consider sufficient is that the goods have not been used or consumed and that they have been exported from the customs territory of the Community to the customs authorities.

Finally, the Union Code states that the extinction of the customs debt following the regularization of the operation which gave rise to a situation of non-compliance (Article 124) does not preclude Member States from possibility of applying sanctions for non-compliance with the customs legislation (Article 125), thus sanctioning the autonomy of the facts constituting the customs debt from those integral to any administrative or criminal sanctions.

\section{Conclusion}

The foundations of the customs debt in the new code have not radically changed, since the Code, is not a new instrument, tailored to the new idea of a customs union advocated by the Community institutions, but presents itself as a synthesis and integration of the customs procedures applied separately in the Member States over the past twenty years, now well established. Given this, there are some novelties. Firstly, the principle of an internal market extended to the whole of the Community has led to the need for customs legislation which provides for general rules and procedures which are capable of ensuring the application of Community tariff and trade measures relating to trade in goods between the Community and third countries. The consideration of the right of traders to a fair treatment, which balances the institutional task of the customs administration to provide for the orderly application of the customs legislation, has led to the provision of ample control possibilities for economic operators on the administration of the administration including the right of data subjects to appeal against their decisions. Finally, but not for this less important change, it is to be found in the great importance of external trade for the interests of the Community which has led, in the new code, to the need to suppress or at least limit, as far as possible, the formalities and customs controls. 


\section{Conflicts of Interest}

The author declares no conflicts of interest regarding the publication of this paper.

\section{References}

Bianca, C. M (1993). The Obligations (ch. IV Italian Civil Code). Milan: Handbook Publisher Giuffre.

Bianca, C. M. (2000). The Obligations (ch. IV Italian Civil Code). Milan: Handbook Publisher Giuffre.

Boria, P. (2008). The Tax System (p. 824 and the Following Pages). Milan: Publisher Utet Giuridica.

Breccia, U. (1991). The Obligations (p. 21 and the Following Pages). In the Treaty of civil law. Milan: Publisher Giuffrè.

Castaldi, L. (1993). Jointly Liable Custom (vol. XXIX, ad vocem). In the Enciclopedia Giuridica. Rome: Publisher Treccani.

Cerioni, F. (2006). Under the European Court the Customs Regime for Inward Processing. In the Tax Jurisprudence Review (n.6/2006). Milan: Publisher Ipsoa.

Cerioni, F. (2013). Entry into Force of the European Union Customs Code (p. 3648 and the Following Pages). In the Italian Tax Law Review. Milan: Publisher Ipsoa.

Daniele, L. (1988). Movement of Goods in Community Law (vol. III., p. 60. and the Following Pages). In the Dig. Disc. Publ. Milan: Publisher Utet.

De Cicco, A. (2002). Imports (vol. XVI, p. 1 the Following Pages). In Enc., the Italian Tax Law Review. Rome: Publisher Treccani.

Falsitta, G. (2003). Tax Law (p. 264 and Following Pages). Milan: Handbook Publisher Cedam.

Falsitta, G. (2010) Handbook on Tax Law, Special Section (p. 893 and the Following Pages). In the Handbook Tax System in Italy. Milan: Publisher Cedam.

Fantozzi, A. (2003). Tax Law (p. 314 and Following Pages). Milan: Handbook Publisher Utet.

Fiorenza, S. (1990). Customs and Customs Duties (p. 124 and the Following Pages). In the Handbook Digesto Disciplina Privatistica. Milan: Publisher Utet.

Giannini, A. D. (1965) Institutions (p. 125 and the Following Pages). In the Handbook Tax Law. Milan: Publisher Cedam.

Luminoso, A. (1984). Mandate, Commission, Expedition (p. 5 and the Following Pages). In the Treaty of Civil and Commercial Law. Milan: Publisher Giuffrè.

Muratori, A. (1980). Drawback. In the Handbook Nuovissimo Digesto italiano (Vol. 3, p. 194). Milan: Publisher Utet.

Muratori, A. (1993). Commentary on the Single Customs. In the Handbook Single Customs (p. 55 and the Following Pages). Milan: Publisher Cedam.

Padovani, F. (2002). Customs Duties (p. 287 and the Following Pages). Milan: Publisher Giuffrè.

Palcchino, T. (2004). The Community Tax Law. In the Handbook Diritto Doganale, delle accise e dei tributi ambientali (p. 155 and the Following Pages). Milan: Publisher Ipsoa.

Parlato, A. (1963). The Tax Manager. In the Handbook Tax Law (p.79 and the Following Pages). Milan: Publisher Giuffrè. 
Potito, E. (1989). Passive Tax Person. In Enciclopedia del Diritto (p. 1226 and the Following Pages, Vol. XLII). Milan: Publisher Utet.

Pugliatti, S. (1935). Institutions Civil Law. In Legal Writings (Vol. I, p. 645 and the Following Pages). Milan: Publisher Giuffrè.

Russo, P. (2003). The Handbook on Tax Law, Special Section (p. 86 and the Following Pages). Milan: Publisher Giuffrè.

Tesauro, F. (2003). Institutions of Tax Law (p. 126 and the Following Pages). Handbook Milan: Publisher Utet. 